Article

\title{
Novel Approach for Fine Ilmenite Flotation Using Hydrophobized Glass Bubbles as the Buoyant Carrier
}

\author{
Pan Chen 1,2, Youchuan Chen 1,2 (D), Hang Liu ${ }^{1,2}$, Haoyu Li ${ }^{3}$, Xujian Chai ${ }^{1,2}$, Xiaolong Lu 1,2 ${ }^{1, \text { Wei Sun }}{ }^{1,2, *}$, \\ Hongbin Wang ${ }^{4}$, Yangyong Luo ${ }^{5}$ and Xianyun Wang ${ }^{5}$
}

1 School of Minerals Processing and Bioengineering, Central South University, Changsha 410083, China; panchen@csu.edu.cn (P.C.); avogadro@csu.edu.cn (Y.C.); liuhang2020@csu.edu.cn (H.L.); chaixujian@csu.edu.cn (X.C.); 185612123@csu.edu.cn (X.L.)

2 Key Laboratory of Hunan Province for Clean and Efficient Utilization of Strategic Calcium-Containing Mineral Resources, Central South University, Changsha 410083, China

3 School of Chemistry and Chemical Engineering, Central South University, Changsha 410083, China; 182311098@csu.edu.cn

4 Design and Research Institute of Panzhihua Iron and Steel Group Mining Co., Ltd., Panzhihua 617000, China; chychjack@126.com

5 Sichuan Anning Iron and Titanium Co., Ltd., Panzhihua 617200, China; chychjack@foxmail.com (Y.L.); wangxianyun@163.com (X.W.)

* Correspondence: sunmenghu@csu.edu.cn; Tel.: +1-350-731-0692

Citation: Chen, P.; Chen, Y.; Liu, H.; Li, H.; Chai, X.; Lu, X.; Sun, W.; Wang, H.; Luo, Y.; Wang, X. Novel Approach for Fine Ilmenite Flotation Using Hydrophobized Glass Bubbles as the Buoyant Carrier. Minerals 2021, 11, 231. https://doi.org/10.3390/ $\min 11030231$

Academic Editor: Saeed Farrokhpay

Received: 6 January 2021

Accepted: 13 February 2021

Published: 25 February 2021

Publisher's Note: MDPI stays neutral with regard to jurisdictional claims in published maps and institutional affiliations.

Copyright: (c) 2021 by the authors. Licensee MDPI, Basel, Switzerland. This article is an open access article distributed under the terms and conditions of the Creative Commons Attribution (CC BY) license (https:// creativecommons.org/licenses/by/ $4.0 /)$.

\begin{abstract}
Ilmenite disseminated grain size is relatively fine, and it must be finely ground to fully separate ilmenite from gangue and then produce fine-grained minerals, which deteriorates flotation. A novel method using buoyant carriers to improve the recovery of fine ilmenite in froth flotation was introduced in this study. Hydrophobized glass bubbles (HGB) as carrier materials were obtained by an efficient, simple modification of ordinary glass bubbles. The carrier flotation of fine ilmenite in the presence of HGB was investigated by micro flotation tests, X-ray diffractometer analysis, Fourier transform infrared (FTIR), optical microscope observation, and the extended DLVO theory (XDLVO). Micro-flotation results showed that the recovery of fine ilmenite in presence of HGB was 37.7\% higher than that when using $\mathrm{NaOL}$ alone at $\mathrm{pH}$ 6. FTIR analysis and optical microscope observation revealed that fine ilmenite particles can be closely attached on the HGB surface to increase apparent particle size considerably. The data calculated from the DLVO theory indicated that the acid-base interaction force determined the adsorption between two hydrophobic particles.
\end{abstract}

Keywords: ilmenite; flotation; carrier; fine particles; hydrophobized glass bubbles; extended DLVO theory

\section{Introduction}

As a strategic metal, titanium has wide applications in the fields of medicine and aerospace. Titanium ores, which are the crucial footstone of the titanium industry, include ilmenite $\left(\mathrm{FeTiO}_{3}\right)$ and rutile $\left(\mathrm{TiO}_{2}\right)$, and it is reported that ilmenite in vanadium-titanium magnetite account for about $90 \%$ of China's titanium resources [1,2]. Before the titanium metal extraction, the processing of titanium-bearing ores mainly through grinding, accompanied by beneficiation methods, such as flotation, heavy media separation, and magnetic separation to obtain concentrates. Historically, flotation is the most efficient method to separate ilmenite from other silicon-containing minerals [3]. However, restricted by beneficiation methods, the recycling utilization rate of Panzhihua ilmenite is low, especially the fine-grained ilmenite $(<20 \mu \mathrm{m})$, and, due to the small mass and large specific surface area, its recovery is recognized as a problem of mineral processing and also the most outstanding and urgent problem in comprehensive utilization of titanium resources in this region. Therefore, the recovery of fine ilmenite remains a highly challenging problem and attracts researchers' attention. 
The range of mineral particle size for flotation is strictly limited (about 20-80 $\mu \mathrm{m}$ ) to achieve a better recovery rate due to the extremely high surface energy of fine-grained ilmenite that disturbs the selectivity of flotation [4]. Figure 1 presents the effect of particle size on ilmenite recovery. The results show that the flotability of ilmenite increases remarkably with an increase in particle size from $10 \mu \mathrm{m}$ to $60 \mu \mathrm{m}$. Therefore, floatability greatly improves as particle size reaches the intermediate zone $(37-74 \mu \mathrm{m}$ in general). However, because fine particles $(<20 \mu \mathrm{m})$ have a high surface area energy, a large specific surface area, and a small mass, they are deflected by hydraulic drag forces [5]. Therefore, under mechanical stirring, fine particles move along the fluid streamline around bubbles instead of colliding with them [6-8]. Fine particle flotation results in an extremely inefficient process performance, marked by reduced flotation recovery and affecting the concentrate grade [9]. Ores become more complicated, disseminated, and consequently more difficult to process because mineral resources have been exploited over time. The problem of fine particle flotation has become increasingly prominent and important. Several alternatives have been proposed to improve bubble-particle collision efficiency and address this problem by reducing the bubble size or increasing the apparent particle size [10-13]. Furthermore, the technique of magnifying the apparent particle size is achieved by increasing the specific surface area and mass of fine mineral particles to reduce surface area energy. These techniques induce fine particles to form flocs or aggregates [14-16]. Several alternatives including selective flocculation, shear flocculation, carrier flotation, and particle agglomeration have been proposed [17-19].

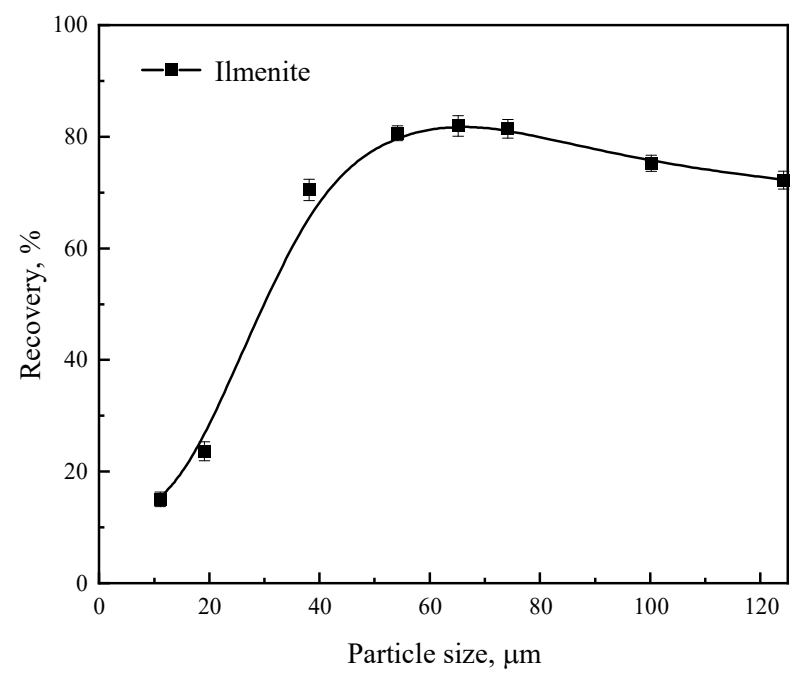

Figure 1. Effect of particle size on flotation recovery of ilmentie treated with sodium oleate ( $\mathrm{pH}$ 6.0, $2.0 \times 10^{-4} \mathrm{~mol} \cdot \mathrm{L}^{-1}$ sodium oleate).

Since American scholars applied carrier flotation to remove titanium-containing impurities in kaolin in 1961, carrier flotation has attracted worldwide attention, and a systematic study was conducted on the application and mechanism of auto-carrier flotation [20-22]. Carrier flotation can be regarded as coarse-grained minerals with good floatability as a carrier, carrying fine-grained minerals, and then recovering "carrier-fine mineral" aggregates by conventional flotation [23]. The carrier for flotation can be divided into two sections: (a) Minerals, which have been studied by the extended DLVO theory, effects of above parameters on carrier flotation by contact angle, zeta potential, and other measurements of particle surface, and (b) Nonmineral materials, which have not been studied widely [24-26]. However, mineral material carrier flotation, which was researched sufficient in previous study, was developed stagnate due to poor hydrophobicity and high density. In the authors' view, nonmineral material carriers accomplish the following properties to improve the recovery of fine particles in flotation: 
Density lower than water density. Carrier material with a density lower than water density would assist optimum levels of recovery.

High hydrophobicity level to selectively recover target mineral particles.

Particle size 5-10 times larger than mineral particles. Therefore, in order to collect mineral particles of $10 \mu \mathrm{m}$ (on average), a carrier size of $50-150 \mu \mathrm{m}$ is deliberated as acceptable.

Considering these characteristics, glass bubbles have been identified as potential carrier materials. In 2020, S. Arriagada et al. applied a kind of nonmineral materialhydrophobized glass bubble (HGB) — as a carrier into the flotation of fine bornite [27]. So far, there have been relatively few studies on fine particles with poor floatability. Therefore, based on this conclusion and experimental results, HGB was introduced as a carrier material to augment the apparent particle size in this study. Moreover, the adhesion mechanism of ilmenite onto the HGB surface was thoroughly investigated in a sodium oleate (NaOL) system by using micro-flotation, Fourier transform infrared (FTIR), extended DLVO (XDLVO) theory, and optical microscope observation.

\section{Experimental}

\subsection{Materials and Reagents}

The silica glass bubbles used were purchased from the 3M Company. K20 glass bubbles were used in this work $\left(d_{90}=110 \mu \mathrm{m}, d_{50}=65 \mu \mathrm{m}, d_{10}=30 \mu \mathrm{m}\right.$, and density $\left.=0.20 \mathrm{~g} / \mathrm{cm}^{3}\right)$. The ilmenite and titanaugite samples used in the experiments were obtained from the tailing of magnetic separation of vanadium-titanium magnetite in Panzhihua, Sichuan Province, China. The mineral samples were crushed and dry-ground in a porcelain ball mill and then purified through magnetic and gravity separation. Figure 2 and the $\mathrm{X}$-ray fluorescence results listed in Table 1 indicate that the $\mathrm{TiO}_{2}$ content is $48.51 \%$, but the purities of ilmenite and titanaugite are above $90 \%$, as verified by the X-ray diffraction (XRD) results and chemical composition. Each fine-grained mineral was ground to a diameter smaller than $0.019 \mathrm{~mm}$ and used for subsequent experiments. Analytical-grade $\mathrm{NaOL}$ and sodium silicate purchased from the Sinopharm Chemical Reagent Co., Ltd. (Shanghai, China) were used as collector and depressant, respectively. Acetone was used as mixing cosolvent for the esterified particles, and high-purity 1-butanol $(>99 \% w / w)$ from the Macklin Biochemical Technology Co., Ltd. (Shanghai, China) was used as hydrophobization chemical reagent. Potassium chloride $(\mathrm{KCl})$ was used as background electrolyte for zeta potential measurements. Sodium hydroxide $(\mathrm{NaOH})$ and sulfuric acid $\left(\mathrm{H}_{2} \mathrm{SO}_{4}\right)$ stock solutions were used to adjust the $\mathrm{pH}$, and deionized (DI) water (resistivity $=18.3 \mathrm{M} \cdot \mathrm{cm}$ ) was used throughout the experiments.
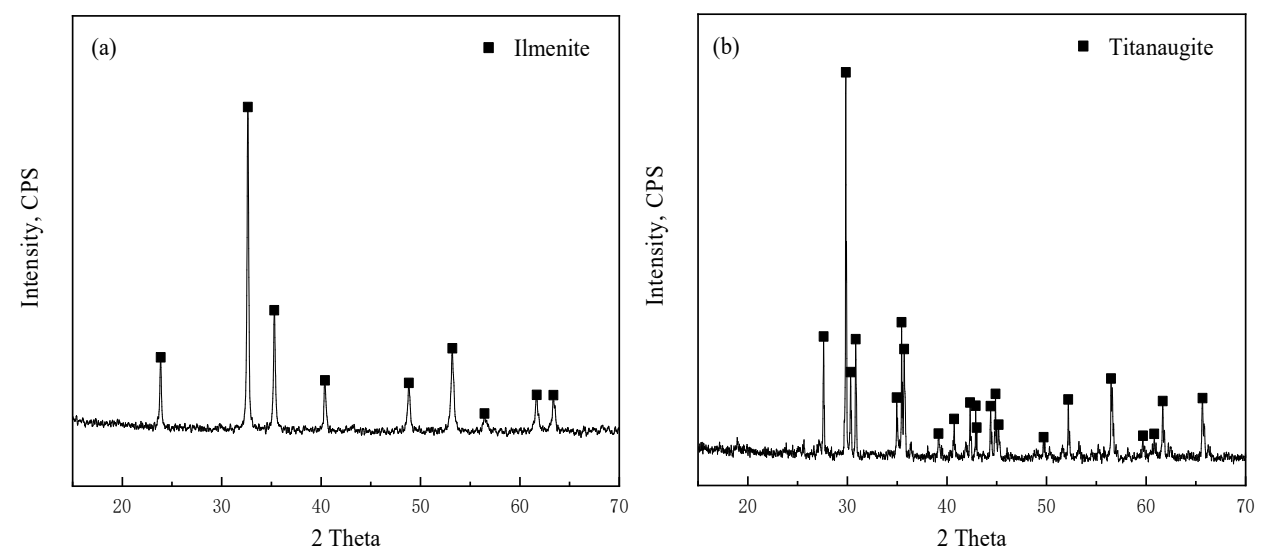

Figure 2. X-ray diffraction spectra of (a) ilmenite and (b) titanaugite. 
Table 1. Chemical compositions of purified ilmenite and titanaugite samples (mass fraction, \%).

\begin{tabular}{cccccccc}
\hline Sample & $\mathrm{TiO}_{\mathbf{2}}$ & $\mathrm{Fe}_{\mathbf{2}} \mathbf{O}_{\mathbf{3}}$ & $\mathbf{S i O}_{\mathbf{2}}$ & $\mathbf{C a O}$ & $\mathbf{M g O}$ & $\mathbf{A l}_{\mathbf{2}} \mathbf{O}_{\mathbf{3}}$ & Others \\
\hline Ilmenite & 48.51 & 35.39 & 4.67 & 1.35 & 4.84 & 1.61 & 3.63 \\
Titanaugite & 3.50 & 14.38 & 15.60 & 40.34 & 10.56 & 6.72 & 8.90 \\
\hline
\end{tabular}

\subsection{Materials Characterization}

The chemical composition of the samples was detected using an X-ray diffractometer. The phase composition was analyzed with the aid of Jade6.5 software.

The zeta potential of HGB and ilmenite was measured by a Delsa-440sx zeta meter (Brea, CA, USA). First, $20 \mathrm{mg}$ of the samples was added to $40 \mathrm{~mL}$ of electrolyte solution $\left(10^{-3} \cdot \mathrm{mol} \cdot \mathrm{L}^{-1} \cdot \mathrm{KCl}\right)$ for the measurements. The required $\mathrm{pH}$ was adjusted by $\mathrm{H}_{2} \mathrm{SO}_{4}$ and $\mathrm{NaOH}$ solutions for $3 \mathrm{~min}$, followed by another $3 \mathrm{~min}$ for adding the desired concentration of $\mathrm{NaOL}$ collector. The suspension was stirred with a magnetic stirrer for $14 \mathrm{~min}$, then settled for $10 \mathrm{~min}$. The supernatant was used for measurement. The average of three individual measurements was used for analysis.

The contact angles of ilmenite and HGB treated with or without NaOL were measured by a contact angle goniometer (Dropmaster 300, Kyowa Interface Science Co., Ltd., Tokyo, Japan).

The laser-based particle size was measured with Master-size 2000 (Malvern, UK) to obtain the size distribution of fine-grained mineral particles.

\subsection{Optical Microscope Observation}

An optical microscope (OLYMPUS CX31, Tokyo, Japan) was used to observe the state of ilmenite particles (size distributions of $-19 \mu \mathrm{m}$ ) before and after the collector and HGB addition in an aqueous suspension. The prepared condition was the same as that in the micro-flotation experiment ( $\mathrm{pH}: 6.0, \mathrm{NaOL}$ concentration: $4.0 \times 10^{-4} \cdot \mathrm{mol} \cdot \mathrm{L}^{-1}$ ). A small amount of suspension was dropped on the microslide and then moved to the microscope for observation after natural drying.

\subsection{FTIR Measurements}

FTIR measurements were recorded using a Nicolet 380 FTIR spectrometer (Thermo Fisher Scientific, Waltham, MA, USA) and the KBr reflection method. First, the mineral sample was finely ground to smaller than $5 \mu \mathrm{m}$ before contacting with the collector. Then, $1 \mathrm{~g}$ of the mineral sample was added to $40 \mathrm{~mL}$ of aqueous solution with or without $\mathrm{NaOL}$ $\left(4.0 \times 10^{-4} \mathrm{~mol} \cdot \mathrm{L}^{-1}\right)$ at $\mathrm{pH}$ 6.0. The suspension was filtered after $20 \mathrm{~min}$ of mechanical stirring. The precipitation was washed five times with DI water and vacuum-dried at $60^{\circ} \mathrm{C}$. The $2.0 \%$ powder was mixed with dry $\mathrm{KBr}$ pressing disc pellets for measurements.

\subsection{Glass Bubbles Hydrophobization}

HGB is obtained by hydrophobizing the silica surface of "glass bubbles". "Glass bubbles" must be esterified with straight chain alcohols to produce chemically bonded alkane coatings, obtain HGB, and make the original glass bubbles (OGB) surface hydrophobic [27]. Reactions need to be carried out in excess reagents without relying on precise reagent concentrations to prevent secondary or polymerization reactions [28]. The general esterification reaction scheme is given in Equation (1) [29], where the reaction occurs in surface silanol groups:

$$
\equiv \mathrm{Si}-\mathrm{OH}+\mathrm{HO}-\mathrm{R}_{\mathrm{x}} \mathrm{H}_{\mathrm{y}} \leftrightarrow \mathrm{Si}-\mathrm{O}-\mathrm{R}_{\mathrm{x}} \mathrm{H}_{\mathrm{y}}+\mathrm{H}_{2} \mathrm{O}
$$

First, $50 \mathrm{~g}$ of silica particles was reacted with $130 \mathrm{~g}$ 1-butanol and boiled in a $500 \mathrm{~mL}$ insulated round-bottom flask under reflux for $7 \mathrm{~h}$. A magnetic stirrer was used to stir continuously and prevent the mixture from coagulating. A condenser with a $\mathrm{CaCl}_{2}$ drying tube on top was used to prevent the entry of moisture from the surrounding environment. 
Once the boiling period was finished, the coated particles were centrifuged and washed twice in acetone and once in ethanol to ensure the complete removal of excess reagent.

\subsection{Micro-Flotation Experiment}

Micro-flotation experiments were conducted in an XFGII flotation machine with a stirring rate of $1700 \mathrm{rpm}$. The $2 \mathrm{~g}$ purified mineral sample and $40 \mathrm{~mL}$ of deionized water were mixed in each test. The suspension $\mathrm{pH}$ was adjusted by $\mathrm{H}_{2} \mathrm{SO}_{4}$ or $\mathrm{NaOH}$ solution by stirring for $3 \mathrm{~min}$. After this period, the depressant was added to the suspension and conditioned for $3 \mathrm{~min}$, followed by the addition of the desired concentration of the collector and conditioning for another $3 \mathrm{~min}$. Then, HGB carrier or OGB was added and stirred for $6 \mathrm{~min}$. Flotation time was limited to $3 \mathrm{~min}$, and froth was scraped out every $10 \mathrm{~s}$. Figure 3 illustrates the flowsheet involved in the micro-flotation test. The concentrates and tailing were filtered, dried, and weighed to calculate the mineral recovery.

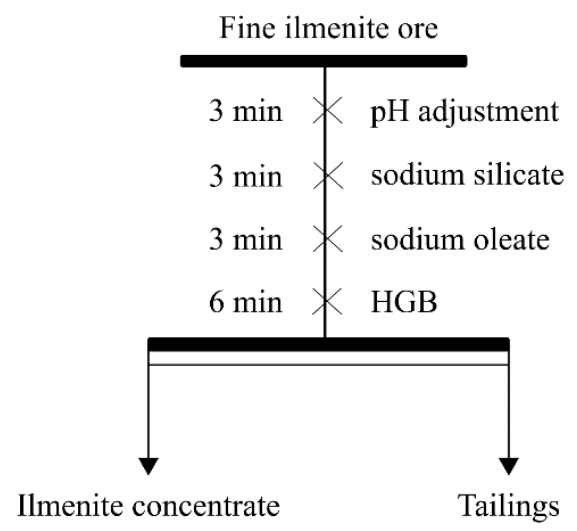

Figure 3. Flowsheet of ilmenite sample flotation.

\section{Results and Discussion}

\subsection{Micro-Flotation}

Figure 4 illustrates the flotation behaviors of ilmenite and titanaugite $(38-74 \mu \mathrm{m})$ using $2.0 \times 10^{-4} \mathrm{~mol} \cdot \mathrm{L}^{-1}$ of NaOL collector as a function of $\mathrm{pH}$. The results show that the flotability behaviors of ilmenite and titanaugite first increase remarkably and then stabilize above $80 \%$ when $\mathrm{pH}$ increases from 2.0 to 12.0 , and floatability of titanaugite trends are remarkably similar to ilmenite. The optimal pulp $\mathrm{pHs}$ for ilmenite and titanaugite are around 6.0 and 7.0, respectively, and the maximum recovery difference between ilmenite and titanaugite is $47.42 \%$ at $\mathrm{pH} 6.0$.

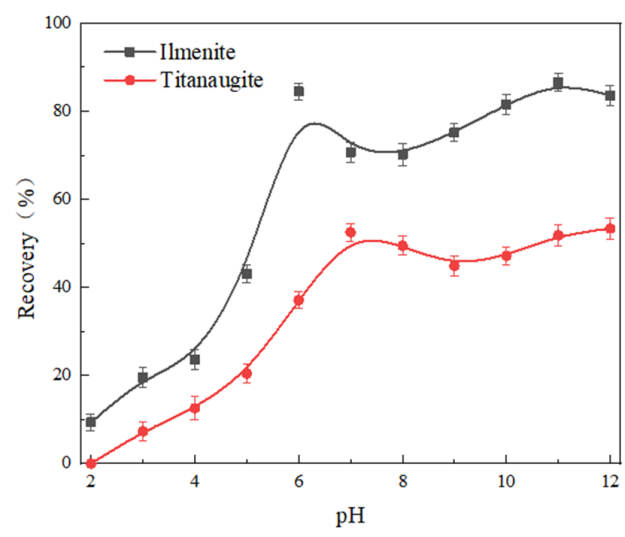

Figure 4. Effect of $\mathrm{pH}$ on flotation recovery of ilmentie and titanaugite treated with sodium oleate (the mineral size distributions of $38-74 \mu \mathrm{m}, 2.0 \times 10^{-4} \mathrm{~mol} \cdot \mathrm{L}^{-1}$ sodium oleate). 
Figure 5 shows the effect of HGB dosage on floatability of fine ilmenite and fine titanaugite at a $\mathrm{pH}$ of 6.0. It further showed that the flotation recoveries of ilmenite and titanaugite increased with the HGB dosage. When the HGB dosage was more than $0.02 \mathrm{~g}$, the flotation recoveries of both minerals occurred at high platforms.

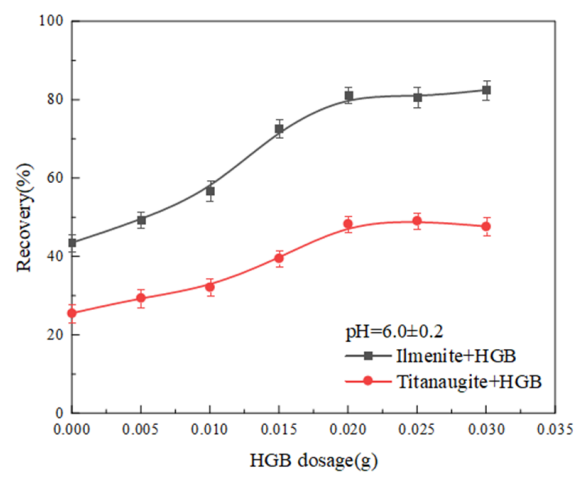

Figure 5. Effect of HGB dosage on fine ilmenite and fine titanaugite recoveries (the mineral size distributions of $0-19 \mu \mathrm{m}, 4.0 \times 10^{-4} \mathrm{~mol} \cdot \mathrm{L}^{-1}$ sodium oleate).

Figure 6 shows the relationship between fine-grained minerals and flotation recovery by NaOL of $4.0 \times 10^{-4} \mathrm{~mol} \cdot \mathrm{L}^{-1}$ as a function of $\mathrm{pH}$. In the presence of collector $\mathrm{NaOL}$, the recovery of ilmenite and titanaugite $(0-19 \mu \mathrm{m})$ has a poor floatability. The flotation recovery of ilmenite in acidic aqueous solutions first increases sharply with the increase of $\mathrm{pH}$, stabilizes above $50 \%$ when $\mathrm{pH}$ is over 5.0 , and continues to increase in a weakly alkaline environment. Floatability of fine titanaugite trends is remarkably similar to fine ilmenite. The effect of OGB addition on the flotation behavior was investigated, and the results are shown in Figure 6. The flotation recoveries of two minerals are nearly unchanged with an increase of $\mathrm{pH}$ from 2.0 to 12.0 in the presence of mixed OGB, indicating that OGB cannot promote flotation performance. However, HGB leads to an effective increase for both minerals. The results denote that when $\mathrm{NaOL}$ is used as the collector at $\mathrm{pH}$ 5.0-8.0, the recovery of ilmenite mixed with HGB reaches a maximum at and above $\mathrm{pH}$ 6.0, the recovery of ilmenite is only approximately $40 \%$, but the recovery of ilmenite mixed with HGB is close to $85 \%$. However, the maximum recovery difference between two minerals is only $32.87 \%$. Therefore, the recovery difference between two minerals is no more than $33 \%$, and the flotation separation of the two minerals is difficult to achieve [30]. Otherwise, when $\mathrm{pH}$ increases from 10 to 12 , the same as normal size minerals, the floatability of both minerals is excellent, which differs from the results of previous studies [31]. This finding may be related to the decrease in the surface tension of $\mathrm{NaOL}$ and the sharp increase in foamability as $\mathrm{pH}$ increases, resulting in a further decrease in the selectivity of $\mathrm{NaOL}$ [32].

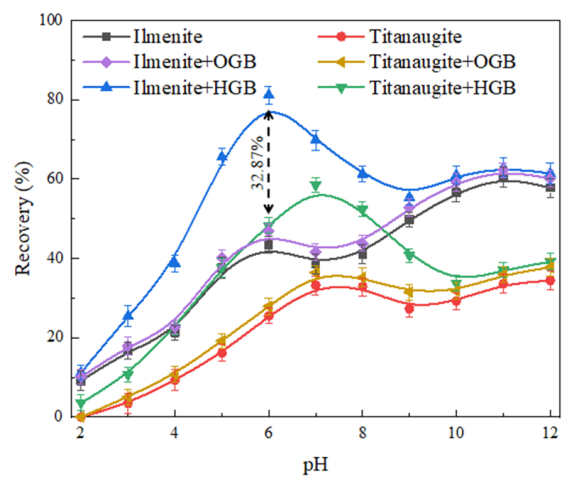

Figure 6. Effect of $\mathrm{pH}$ on flotation recovery of $\mathrm{NaOL}$ adsorbed fine ilmenite and fine titanaugite in the absence and presence of HGB and OGB (the mineral size distributions of 0-19 $\mu \mathrm{m}$, $4.0 \times 10^{-4} \mathrm{~mol} \cdot \mathrm{L}^{-1}$ sodium oleate, HGB/OGB dosage $=0.02 \mathrm{~g}$ ). 
In the usual $\mathrm{pH}$ range (5.0-8.0), ilmenite and titanaugite mixed with HGB have an excellent floatability, and accomplishing the flotation separation of the two minerals is difficult using a single collector. Therefore, sodium silicate $\left(10 \mathrm{mg} \cdot \mathrm{L}^{-1}\right)$ was used in the carrier flotation of ilmenite to hinder the adsorption of $\mathrm{NaOL}$ collector on the titanaugite surface, flocculate fine titanaugite particles, and prevent titanaugite from floating together with ilmenite. Figure 7 shows that after adding $10 \mathrm{mg} \cdot \mathrm{L}^{-1}$ sodium silicate, the floatability of ilmenite is nearly unaffected, while titanaugite recovery declines remarkably [33]. In conclusion, HGB can improve the flotation recovery of ilmenite across a wide range of pulp $\mathrm{pH}$ values. The flotation separation of the two minerals can be achieved at $\mathrm{pH} 6.0$ and recovery difference between ilmenite and titanaugite increased from approximately $32.87 \%$ to $52.11 \%$.

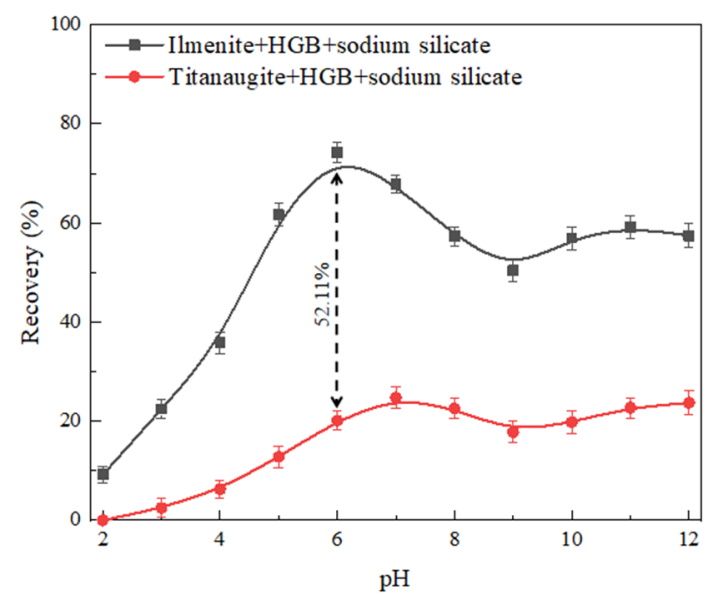

Figure 7. Effect of $\mathrm{pH}$ on flotation recovery of fine ilmenite and fine titanaugite mixed with HGB after treated with sodium oleate and sodium silicate (the mineral size distributions of $0-19 \mu \mathrm{m}$, $4.0 \times 10^{-4} \mathrm{~mol} \cdot \mathrm{L}^{-1}$ sodium oleate, $10 \mathrm{mg} \cdot \mathrm{L}^{-1}$ sodium silicate, HGB dosage $=0.02 \mathrm{~g}$ ).

\subsection{FTIR Analysis}

Figure 8 shows the infrared spectra of NaOL, ilmenite, HGB, and both materials treated with $\mathrm{NaOL}\left(4.0 \times 10^{-4} \mathrm{~mol} \cdot \mathrm{L}^{-1}\right)$ at a $\mathrm{pH}$ of 6.0 . On the IR spectrum of NaOL, the bands at 2922.80 and $2851.68 \mathrm{~cm}^{-1}$ are previously attributed to the $\mathrm{C}-\mathrm{H}$ stretching vibrations of methyl and methylene $-\mathrm{CH}$, respectively. The bands at 1561.00 and $1449.36 \mathrm{~cm}^{-1}$ belong to the $-\mathrm{COO}-$ vibration, the band at $1561.00 \mathrm{~cm}^{-1}$ corresponds to the asymmetric stretching vibration of $-\mathrm{COOC}-$, and the band at $1449.36 \mathrm{~cm}^{-1}$ corresponds to the symmetric stretching vibration of -COOC- [34].

Figure $8 \mathrm{~b}$ shows that the peaks at about 545 and $458 \mathrm{~cm}^{-1}$ are characteristic bands for ilmenite. The peaks at approximately 1632 and $3443 \mathrm{~cm}^{-1}$ could be attributed to the bending mode of adsorbed water, in which the peak at approximately $3443 \mathrm{~cm}^{-1}$ corresponds to the stretching vibration of $-\mathrm{OH}$ [35]. Compared with the IR spectrum of purified ilmenite, new peaks shift to 2919,2850,1544, and $1463 \mathrm{~cm}^{-1}$, bonds at 2919 and $2850 \mathrm{~cm}^{-1}$ can correspond to the stretching vibration of $-\mathrm{CH}_{2}-$ and $-\mathrm{CH}_{3}-$ in $\mathrm{NaOL}$, and these shifts indicate the adsorption of oleate species on the ilmenite surface through chemisorption [36].

The FTIR spectra of HGB and HGB treated with NaOL at a pH of 6.0 are shown in Figure 8c. On the spectrum of untreated HGB, the bands at approximately 2923 and $2856 \mathrm{~cm}^{-1}$ are attributed to the $\mathrm{C}-\mathrm{H}$ stretching vibration of the $-\mathrm{CH}_{2}-$ and $-\mathrm{CH}_{3}-$ groups, respectively. The small peaks indicate that the reaction in Equation (1) is successful. Figure $8 \mathrm{c}$ shows that the stronger peaks at approximately 2922 and $2852 \mathrm{~cm}^{-1}$ and the new bond at approximately $1560 \mathrm{~cm}^{-1}$ result from the -COOC- asymmetric stretching vibration. The characteristic peaks of oleate species shift weakly due to physisorption of the oleate species on the surface of HGB. 

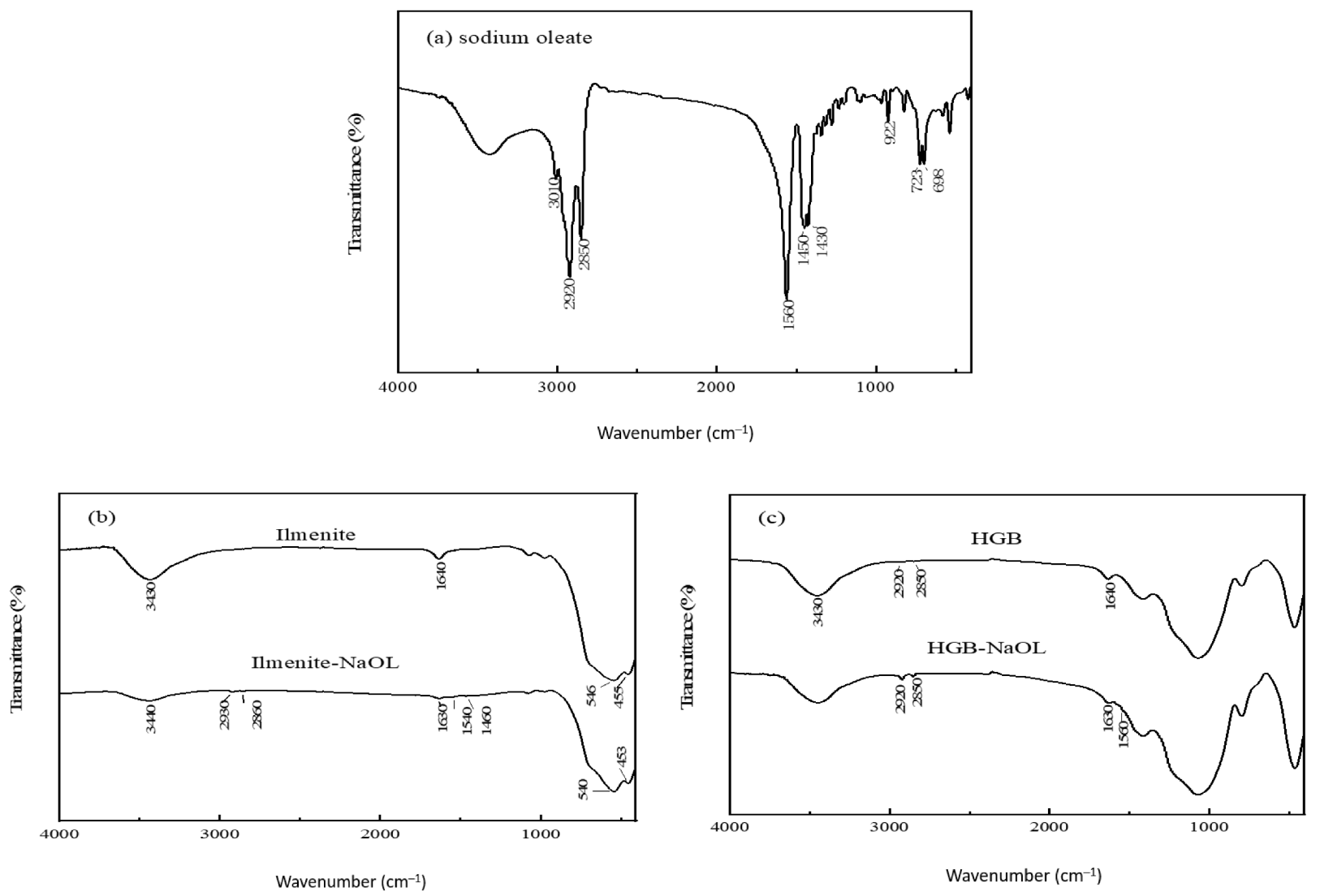

Figure 8. FTIR spectra of (a) NaOL, (b) ilmenite, and (c) HGB under various conditions.

\subsection{Estimation of Interaction Energies by Extended DLVO Theory}

The classic DLVO theory was proposed by Deryagin and Landau, and Verwey and Overbeek [37]. It explains the stability of colloids, including electrical double-layer interaction forces and London-van der Waals interaction forces. The classic DLVO theory cannot fully explain the flotation behavior of mineral particles due to the existence of various flotation agents in slurry. Van Oss et al. formulated the XDLVO theory. They added an acid-based interaction component built on the electron-donating and electron-accepting interactions between polar moieties in an aqueous solution. In general, small particle interaction energies can be explained by surface thermodynamics and the XDLVO theory, in which the interaction energy between ilmenite and HGB is calculated as a function of separation distance [38].

According to the XDLVO theory, the total energy of interaction $V_{\mathrm{T}}$ is determined as follows:

$$
V_{\mathrm{T}}=V_{\mathrm{E}}+V_{\mathrm{H}}+V_{\mathrm{W}}
$$

where $V_{\mathrm{E}}$ is the electrostatic interaction energy, $V_{\mathrm{W}}$ is the London-van der Waals dispersion energy, and $V_{\mathrm{H}}$ is the acid-base interaction energy.

The electrostatic force $V_{\mathrm{E}}$ between HGB and ilmenite can be expressed by the following equation for the sphere-sphere system:

$$
V_{\mathrm{E}}=\frac{\pi \varepsilon a_{1} a_{2}\left(\varphi_{1}^{2}+\varphi_{2}^{2}\right)}{a_{1}+a_{2}} \times\left[\frac{2 \varphi_{1} \varphi_{2}}{\varphi_{1}^{2}+\varphi_{2}^{2}} \ln \frac{1+\exp (-\kappa H)}{1-\exp (-\kappa H)}+\ln \{1-\exp (-2 \kappa H)\}\right]
$$

where $\varepsilon=\varepsilon_{0} \varepsilon_{r}, \varepsilon_{0}$ is absolute dielectric constant $\left(8.854 \times 10^{-12} \mathrm{C}^{-2} \cdot \mathrm{J}^{-1} \cdot \mathrm{m}^{-1}\right), \varepsilon_{r}$ is the dielectric constant of the medium, and $78.5 \mathrm{C}^{-2} \mathrm{~J}^{-1} \mathrm{~m}^{-1}$ is the aqueous medium's dielectric constant, such that $\varepsilon=6.95 \times 10^{-10} \mathrm{C}^{-2} \mathrm{~J}^{-1} \mathrm{~m}^{-1}$ [39]; $\varphi_{1}$ and $\varphi_{2}$ are the Stern potentials 
of the HGB and mineral, respectively, which are often replaced with $\zeta$-potential; $a_{1}$ and $a_{2}$ are the radius of the HGB and mineral particle, respectively, which are measured with Master-size 2000; $\mathrm{H}$ is the minimum separation distance between the HGB and mineral particle; and the reciprocal of the Debye length, $\mathrm{K}^{-1}$, is $9.61 \mathrm{~nm}$ calculated via $\kappa^{-1}=0.304 / \sqrt{\left[10^{-3} M K C L\right]} \mathrm{nm}$. In the NaOL solution $\left(4.0 \times 10^{-4} \mathrm{~mol} \cdot \mathrm{L}^{-1}\right)$ of $\mathrm{pH} 6.0$, the $\zeta$-potentials of HGB and ilmenite measured by a Delsa-440sx zeta-meter are -60.8 and $-91.6 \mathrm{mV}$, respectively.

For the HGB-NaOL-ilmenite system, the London-van der Waals energy dispersion $V_{\mathrm{W}}$ can be obtained from the following Equation:

$$
V_{\mathrm{W}}=-\frac{a_{1} a_{2}}{6\left(a_{1}+a_{2}\right)}\left[\frac{A_{1}}{H}+\frac{A_{2}}{H+\delta_{1}}+\frac{A_{3}}{H+\delta_{2}}+\frac{A_{4}}{H+\delta_{1}+\delta_{2}}\right]
$$

where $a_{1}$ and $a_{2}$ represent the radius of the HGB and mineral particle, respectively; $A_{1}, A_{2}$, $A_{3}$, and $A_{4}$ are the Hamaker constants for the mineral particle $\mathbf{P}$ interacting with HGB $\mathbf{B}$ in a medium (water) $\mathbf{W}$ with collector $(\mathrm{NaOL}) \mathbf{C}$ over the minimum separation distance $\mathrm{H} ; \delta_{1}$ and $\delta_{2}$ are the thickness of the adsorbent layer on the surface of mineral particle and HGB, respectively. $A_{1}, A_{2}, A_{3}$, and $A_{4}$ could be calculated as follows:

$$
\begin{aligned}
& A_{1}=\left(\sqrt{A_{\mathrm{C}}}-\sqrt{A_{\mathrm{W}}}\right)\left(\sqrt{A_{\mathrm{P}}}-\sqrt{A_{\mathrm{W}}}\right) \\
& A_{2}=\left(\sqrt{A_{\mathrm{P}}}-\sqrt{A_{\mathrm{C}}}\right)\left(\sqrt{A_{\mathrm{C}}}-\sqrt{A_{\mathrm{W}}}\right) \\
& A_{3}=\left(\sqrt{A_{\mathrm{C}}}-\sqrt{A_{\mathrm{W}}}\right)\left(\sqrt{A_{\mathrm{B}}}-\sqrt{A_{\mathrm{C}}}\right) \\
& A_{4}=\left(\sqrt{A_{\mathrm{P}}}-\sqrt{A_{\mathrm{C}}}\right)\left(\sqrt{A_{\mathrm{B}}}-\sqrt{A_{\mathrm{C}}}\right)
\end{aligned}
$$

where $A_{\mathrm{P}}, A_{\mathrm{B}}, A_{\mathrm{W}}$, and $A_{\mathrm{C}}$ refer to the Hamaker constant for the mineral particle, HGB, medium (water), and collector (NaOL), respectively. The Hamaker constants of ilmenite, HGB, water, and $\mathrm{NaOL}$ are $19.7 \times 10^{-20} \mathrm{~J}, 15 \times 10^{-20} \mathrm{~J}, 3.7 \times 10^{-20} \mathrm{~J}$, and $4.7 \times 10^{-20} \mathrm{~J}$, respectively [40].

Hydrophobic interaction energy $V_{\mathrm{H}}$ can be determined by the following relationship (sphere-sphere system) [41]:

$$
V_{\mathrm{H}}=\frac{2 \pi a_{1} a_{2}}{\left(a_{1}+a_{2}\right)} h_{0}\left(V_{\mathrm{H}}^{0}\right) \exp \left(\frac{H_{0}-H}{h_{0}}\right)
$$

where $a$ is the radius of the particle; $h_{0}$ is the correlation length of the molecules in the liquid; $\mathrm{H}_{0}$ is the minimum separation distance between HGB and ilmenite surfaces; $a_{1}$ and $a_{2}$ are the radii of the HGB and mineral particle, respectively; and $\mathrm{H}$ is the separation distance.

$V_{\mathrm{H}}^{0}$ could be calculated as follows:

$$
\begin{gathered}
V_{\mathrm{H}}^{0}=2\left(\sqrt{\gamma_{b}^{+}}-\sqrt{\gamma_{p}^{+}}\right)\left(\sqrt{\gamma_{b}^{-}}-\sqrt{\gamma_{p}^{-}}\right)-2\left(\sqrt{\gamma_{b}^{+}}-\sqrt{\gamma_{l}^{+}}\right)\left(\sqrt{\gamma_{b}^{-}}-\sqrt{\gamma_{l}^{-}}\right) \\
-2\left(\sqrt{\gamma_{p}^{+}}-\sqrt{\gamma_{l}^{+}}\right)\left(\sqrt{\gamma_{p}^{-}}-\sqrt{\gamma_{l}^{-}}\right)
\end{gathered}
$$

where $b, p$, and $w$ represent HGB, ilmenite, and liquid, respectively, and $\gamma+$ and $\gamma-$ represent the electron acceptor and electron donor parameters, respectively.

The contact angles of liquids on the solid phase were measured by a contact angle goniometer to calculate the surface tension parameters $\left(\gamma_{s}^{d}, \gamma^{+}\right.$, and $\left.\gamma^{-}\right)$for the HGB or minerals, and contact angle results show in Figure 9, the parameters were obtained as follows:

$$
\begin{gathered}
\frac{1}{2}(1+\cos \theta) \gamma_{l}=\sqrt{\gamma_{s}^{d} \gamma_{l}^{d}}+\sqrt{\gamma_{s}^{+} \gamma_{l}^{-}}+\sqrt{\gamma_{s}^{-} \gamma_{l}^{+}} \\
\mathrm{A}=24 \pi H_{0}{ }^{2} \gamma_{s}^{d}
\end{gathered}
$$

where $s$ and $l$ represent solid (HGB or mineral) and liquids, respectively, and $\gamma$ and $\gamma_{s}^{d}$ represent the surface tension and a polar component of the surface tension, respectively. 
The value of oxidized minerals $\gamma_{s}^{+}$is equal to 0 [42]. Equations (7) and (8) could be simplified as follows:

$$
\begin{gathered}
V_{\mathrm{H}}^{0}=2 \sqrt{\gamma_{l}^{+}}\left(\sqrt{\gamma_{b}^{-}}-2 \sqrt{\gamma_{l}^{-}}+\sqrt{\gamma_{p}^{-}}\right) \\
\frac{1}{2}(1+\cos \theta) \gamma_{l}=\sqrt{\gamma_{s}^{d} \gamma_{l}^{d}}+\sqrt{\gamma_{s}^{-} \gamma_{l}^{+}}
\end{gathered}
$$

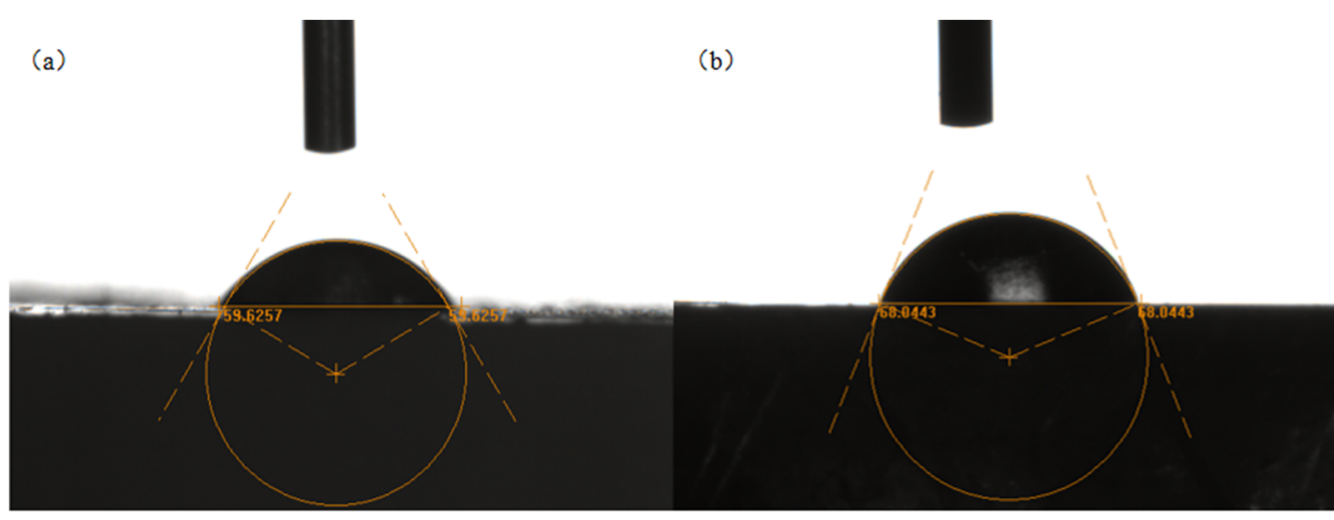

Figure 9. Contact angles of (a) fine ilmenite and (b) HGB in HGB-NaOL-ilmenite system (NaOL concentration: $4.0 \times 10^{-4}$ $\left.\mathrm{mol} \cdot \mathrm{L}^{-1}\right)$.

In this study, $10 \mu \mathrm{m}, 65 \mu \mathrm{m}, 1.3 \mathrm{~nm}, 1.3 \mathrm{~nm}, 10 \mathrm{~nm}, 0.2 \mathrm{~nm}, 72.8 \mathrm{~mJ} \cdot \mathrm{m}^{-2}, 21.8 \mathrm{~mJ} \cdot \mathrm{m}^{-2}$, $25.5 \mathrm{~mJ} \cdot \mathrm{m}^{-2}$, and $25.5 \mathrm{~mJ} \cdot \mathrm{m}^{-2}$ are the specific values of $a_{1}, a_{2}, \delta_{1}, \delta_{2}, h_{0}, \mathrm{H}_{0}, \gamma_{w}, \gamma_{w}^{d}, \gamma_{w}^{+}$, and $\gamma_{w}^{-}$, respectively [18]. The calculation results are shown in Figure 10.

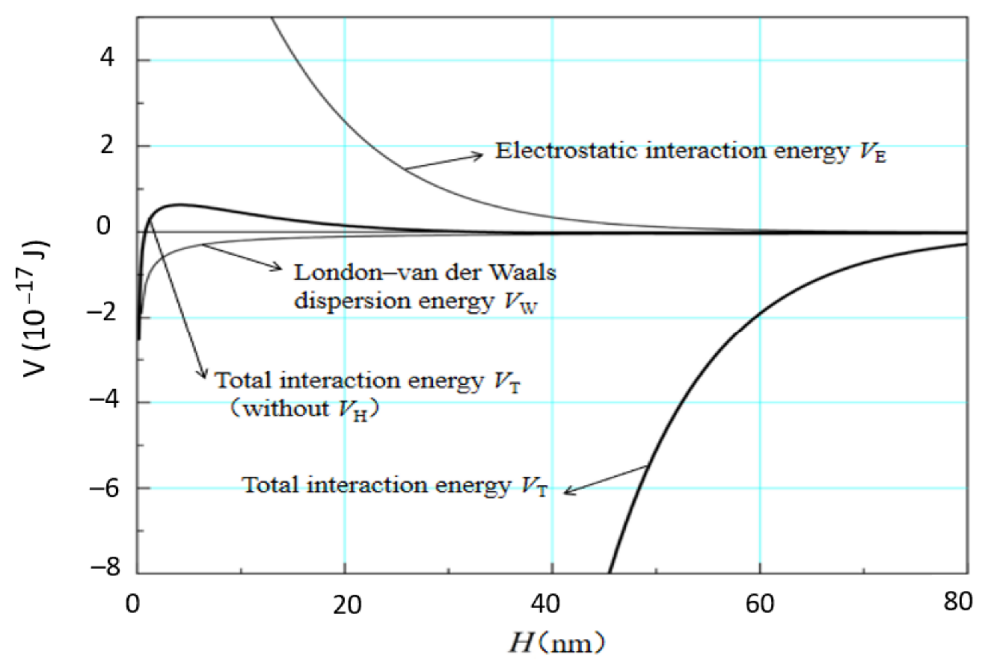

Figure 10. Interaction energy curves between ilmenite and HGB as function of interparticle interaction distance (pH: 6.0, NaOL concentration: $\left.4.0 \times 10^{-4} \mathrm{~mol} \cdot \mathrm{L}^{-1}\right)$.

Figure 10 shows that the electrostatic interaction $\left(V_{\mathrm{E}}\right)$ calculated by Equation (3) is closely related to the zeta potential of ilmenite and HGB. The value of $V_{\mathrm{E}}$ is positive, and $V_{\mathrm{E}}$ is an order of magnitude larger than $V_{\mathrm{W}}$ from Equations (4) and (5) because ilmenite and HGB are highly negatively charged in the NaOL solution. The total interaction energy (without $V_{\mathrm{H}}$ ) exhibits a relatively high energy barrier in close contact $(<20 \mathrm{~nm}$ ), thus making ilmenite particle fail to attach on the HGB surface. However, the optical microscope observation reveals that ilmenite particles and HGB have a good attachment in 
$\mathrm{NaOL}$ solution. The results show that the total interaction energy also depends on acidbase interaction energy $\left(V_{\mathrm{H}}\right)$. The hydrophobic interaction energy calculated by Equations (6), (10) and (11) illustrates that the value of hydrophobic interaction energy is positive, and $V_{\mathrm{H}}$ is an order of magnitude larger than $V_{\mathrm{E}}$, which shows that hydrophobic interaction energy determines the attachment between ilmenite particle and HGB. Total interaction energy increases as the interaction distance between particles decreases. The theoretical calculation value is consistent with the experimental data.

\subsection{Optical Microscope Observation of Ilmenite}

Figure 11 illustrates attachment images of the fine ilmenite mixed HGB treated with or without $\mathrm{NaOL}$ at a concentration $4.0 \times 10^{-4} \mathrm{~mol} \cdot \mathrm{L}^{-1}$. Figure 11 shows that the carrier phenomenon occurs between fine ilmenite particles and carrier HGB under the addition of a collector reagent. Figure 11a shows ilmenite particle has a good dispersion ability in an aqueous solution. Figure $11 \mathrm{~b}$ shows fine ilmenite treated with $\mathrm{NaOL}$, few mineral particles form aggregates, and most of them are still in a dispersed state. Figure 11c,d shows that the mineral particles are surrounded and attached on the surface of the HGB carrier, which indicates that carrier HGB could attach ilmenite treated with the collector, with the addition of a collector reagent and the HGB particle input. In addition, the larger the particle size of the HGB carrier is, the more ilmenite particles can be attached. To sum up, the potential mechanism for the carrier flotation of ilmenite and HGB (Figure 12) could be presumed as follows. First, ilmenite is placed in the flotation cell to be treated with $\mathrm{NaOL}$, such that $\mathrm{NaOL}$ is chemisorbed on the ilmenite surface to make ilmenite hydrophobic. Then, hollow glass bubbles after hydrophobization by 1-butanol are added to the flotation cell. The NaOL-treated ilmenite particles collide with HGB particles in the flotation machine. The hydrophobic forces could then form between the alkyl chains of the oleate species and HGB surfaces, causing the aggregation of HGB and ilmenite particles. The glass bubble is hollow and has strong natural floatability. The surface of the aggregate formed by the glass bubble and mineral is also covered with hydrophobic groups. The joint action of the two improves the floatability of ilmenite in the solution and forms a new method of flotation of fine ilmenite using the hydrophobic glass bubble as the carrier.

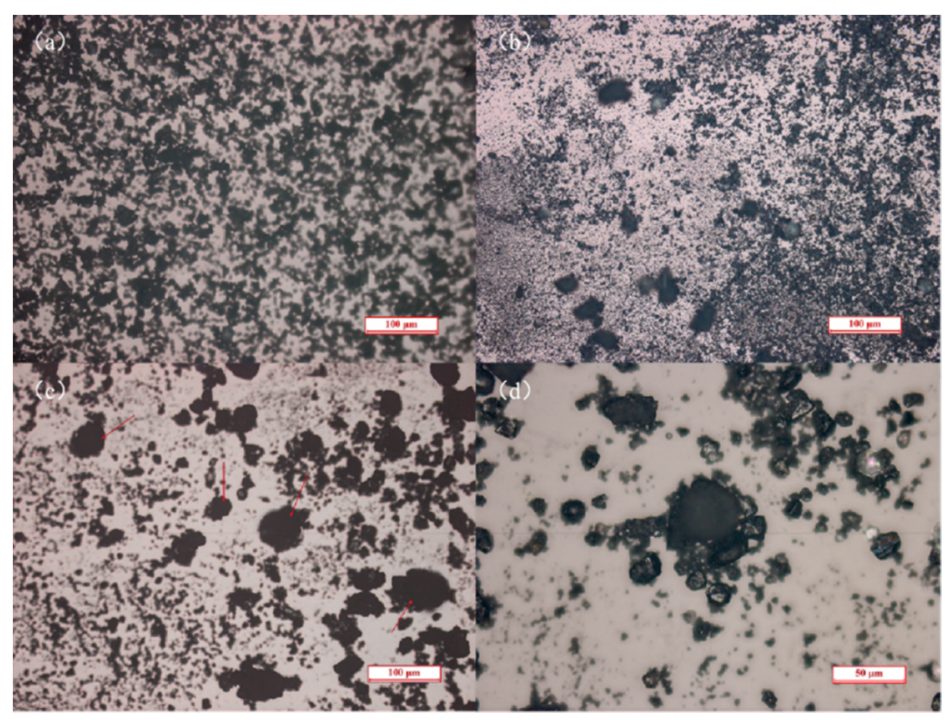

Figure 11. Microscope images of fine ilmenite treated with/without HGB. (a) Ilmenite, (b) ilmenite $+\mathrm{NaOL}$, and (c,d) ilmenite $+\mathrm{NaOL}+\mathrm{HGB}$. (The mineral size distributions of $0-19 \mu \mathrm{m}, \mathrm{pH}=6.0$, $4.0 \times 10^{-4} \mathrm{~mol} \cdot \mathrm{L}^{-1}$ sodium oleate.) 


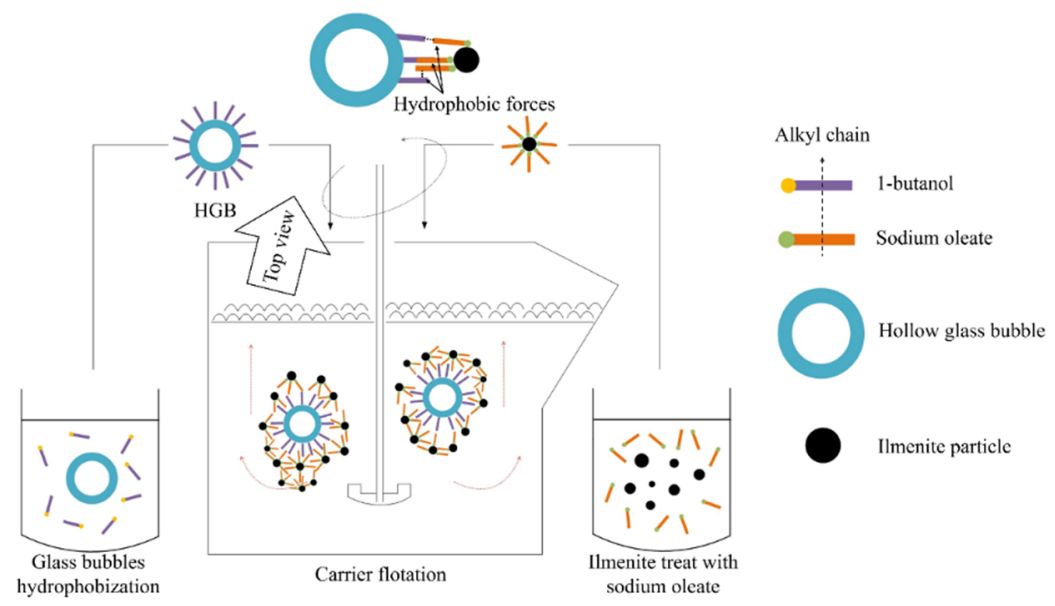

Figure 12. Carrier flotation model of HGB particles promotes ilmenite flotation behavior.

\section{Conclusions}

HGB was studied as the carrier to promote fine-grained ilmenite recovery. The microflotation results showed that the floatability of fine ilmenite and titanaugite remarkably decreased compared with that of coarse ilmenite and titanaugite. HGB could improve the flotation of ilmenite and titanaugite using $\mathrm{NaOL}$ as collector and sodium silicate as depressant to separate ilmenite from titanaugite and achieve the best separation effect at $\mathrm{pH}$ 6.0. The flotation recovery difference between ilmenite and titanaugite increased from approximately $32.87 \%$ to $52.11 \%$. The results of FTIR analysis revealed that NaOL chemisorbed onto the surface of the mineral particles and physisorbed on the HGB surfaces. Optical microscope observation results indicated that ilmenite particles treated with $\mathrm{NaOL}$ solution can be attached on the surface of the HGB, and larger HGB particles can attach more ilmenite particles. According to the XDLVO theory, the total energy of interaction calculation results showed that total energy depended not only on electrostatic and Londonvan der Waals interactions, but also on acid-base interactions. The surface free energy and zeta potential of mineral and carrier were the main factors affecting the acid-base interaction force. The acid-base interactions force determined whether two hydrophobic particles can stick together. Most importantly, adhesion behaviors between mineral and HGB, which was lacking in previous studies, was comprehensively explained here.

Author Contributions: Conceptualization, P.C. and Y.C.; methodology, P.C., Y.C., and H.L. (Hang Liu); software, X.L.; validation, Y.L. and X.W.; formal analysis, H.L. (Haoyu Li); investigation, Y.C. and X.C.; resources, P.C.; data curation, H.W.; writing-original draft preparation, Y.C. and H.L. (Hang Liu); writing-review and editing, P.C. and Y.C.; supervision W.S.; project administration P.C.; funding acquisition, P.C. All authors have read and agreed to the published version of the manuscript.

Funding: The authors acknowledge the support of the Natural Science Foundation of China (52074357), the National key Research and Development Program (2019YFC1803501, 2019YFC1803503, 2018YFC1801804, and 2019YFC0408300), the Natural Science Foundation of China (52074356), and China Postdoctoral Science Foundation (2019M650188).

Institutional Review Board Statement: Not applicable.

Informed Consent Statement: Not applicable.

Data Availability Statement: Not applicable.

Acknowledgments: Not applicable.

Conflicts of Interest: The authors declare no conflict of interest. 


\section{References}

1. Bulatovic, S.; Wyslouzil, D.M. Process development for treatment of complex perovskite, ilmenite and rutile ores. Miner. Eng. 1999, 12, 1407-1417. [CrossRef]

2. Chen, P.; Zhai, J.; Sun, W.; Hu, Y.; Yin, Z.; Lai, X. Adsorption mechanism of lead ions at ilmenite/water interface and its influence on ilmenite flotability. J. Ind. Eng. Chem. 2017, 53, 285-293. [CrossRef]

3. Zhou, M.-F.; Chen, W.T.; Wang, C.Y.; Prevec, S.A.; Liu, P.P.; Howarth, G.H. Two stages of immiscible liquid separation in the formation of Panzhihua-type Fe-Ti-V oxide deposits, SW China. Geosci. Front. 2013, 4, 481-502. [CrossRef]

4. Shellnutt, J.G.; Jahn, B.M. Formation of the Late Permian Panzhihua plutonic-hypabyssal-volcanic igneous complex: Implications for the genesis of Fe-Ti oxide deposits and A-type granites of SW China. Earth Planet. Sci. Lett. 2010, 289, 509-519. [CrossRef]

5. Shahbazi, B.; Rezai, B.; Javad Koleini, S.M. Bubble-particle collision and attachment probability on fine particles flotation. Chem. Eng. Process. Process Intensif. 2010, 49, 622-627. [CrossRef]

6. Ge, L.; Evans, G.M.; Moreno-Atanasio, R. CFD-DEM investigation of the interaction between a particle swarm and a stationary bubble: Particle-bubble collision efficiency. Powder Technol. 2020, 366, 641-652. [CrossRef]

7. Chen, S.; Chen, X.; Wan, D.; Yi, X.; Sun, X.; Ji, L.; Wang, G. A lattice Boltzmann study of the collisions in a particle-bubble system under turbulent flows. Powder Technol. 2020, 361, 759-768. [CrossRef]

8. Hassanzadeh, A.; Hassas, B.V.; Kouachi, S.; Brabcova, Z.; Çelik, M.S. Effect of bubble size and velocity on collision efficiency in chalcopyrite flotation. Colloids Surf. A Physicochem. Eng. Asp. 2016, 498, 258-267. [CrossRef]

9. Nguyen, A.V.; Ralston, J.; Schulze, H.J. On modelling of bubble-particle attachment probability in flotation. Int. J. Miner. Process. 1998, 53, 225-249. [CrossRef]

10. Ireland, P.M.; Jameson, G.J. Collision of a rising bubble-particle aggregate with a gas-liquid interface. Int. J. Miner. Process. 2014, 130, 1-7. [CrossRef]

11. Wang, H.; Yang, W.; Yan, X.; Wang, L.; Wang, Y.; Zhang, H. Regulation of bubble size in flotation: A review. J. Environ. Chem. Eng. 2020, 8, 104070. [CrossRef]

12. Farrokhpay, S.; Filippova, I.; Filippov, L.; Picarra, A.; Rulyov, N.; Fornasiero, D. Flotation of fine particles in the presence of combined microbubbles and conventional bubbles. Miner. Eng. 2020, 155, 106439. [CrossRef]

13. Jameson, G.J. Hydrophobicity and floc density in induced-air flotation for water treatment. Colloids Surf. A Physicochem. Eng. Asp. 1999, 151, 269-281. [CrossRef]

14. Shamlooh, M.; Rimeh, A.; Nasser, M.S.; Al-Ghouti, M.A.; El-Naas, M.H.; Qiblawey, H. Enhancement of flocculation and shear resistivity of bentonite suspension using a hybrid system of organic coagulants and anionic polyelectrolytes. Sep. Purif. Technol. 2020, 237, 116462. [CrossRef]

15. Kostoglou, M.; Karapantsios, T.D.; Evgenidis, S. On a generalized framework for turbulent collision frequency models in flotation: The road from past inconsistencies to a concise algebraic expression for fine particles. Adv. Colloid Interface Sci. 2020, $284,102270$. [CrossRef] [PubMed]

16. Islam, M.T.; Nguyen, A.V. Effect of microturbulence on bubble-particle collision during the bubble rise in a flotation cell. Miner. Eng. 2020, 155, 106418. [CrossRef]

17. Loganathan, S.; Sankaran, S. Surface chemical and selective flocculation studies on iron oxide and silica suspensions in the presence of xanthan gum. Miner. Eng. 2021, 160, 106668. [CrossRef]

18. Roth, C.M.; Unger, K.K.; Lenhoff, A.M. Mechanistic model of retention in protein ion-exchange chromatography. J. Chromatogr. A 1996, 726, 45-56. [CrossRef]

19. Sadowski, Z.; Polowczyk, I. Agglomerate flotation of fine oxide particles. Int. J. Miner. Process. 2004, 74, 85-90. [CrossRef]

20. Zou, W.; Gong, L.; Huang, J.; Zhang, Z.; Sun, C.; Zeng, H. Adsorption of hydrophobically modified polyacrylamide P(AM-NaAAC16DMAAC) on model coal and clay surfaces and the effect on selective flocculation of fine coal. Miner. Eng. 2019, $142,105887$. [CrossRef]

21. Bu, X.; Wang, X.; Zhou, S.; Li, B.; Zhan, H.; Xie, G. Discrimination of Six Flotation Kinetic Models Used in the Conventional Flotation and Carrier Flotation of-74 mu m Coal Fines. ACS Omega 2020, 5, 13813-13821. [CrossRef] [PubMed]

22. Zhao, X.; Meng, Q.; Yuan, Z.; Zhang, Y.; Li, L. Effect of sodium silicate on the magnetic separation of ilmenite from titanaugite by magnetite selective coating. Powder Technol. 2019, 344, 233-241. [CrossRef]

23. Ateşok, G.; Boylu, F.; Çelǐk, M.S. Carrier flotation for desulfurization and deashing of difficult-to-float coals. Miner. Eng. 2001, 14, 661-670. [CrossRef]

24. Zhang, X.; Zhou, X.; Xi, H.; Sun, J.; Liang, X.; Wei, J.; Xiao, X.; Liu, Z.; Li, S.; Liang, Z.; et al. Interpretation of adhesion behaviors between bacteria and modified basalt fiber by surface thermodynamics and extended DLVO theory. Colloids Surf. B Biointerfaces 2019, 177, 454-461. [CrossRef] [PubMed]

25. Hu, N.; Liu, W.; Jin, L.; Li, Y.; Li, Z.; Liu, G.; Huang, D.; Wu, Z.; Yin, H. Recovery of trace Cu2+ using a process of nano-adsorption coupled with flotation: SNP as an adsorbing carrier. Sep. Purif. Technol. 2017, 184, 257-263. [CrossRef]

26. Rubio, J.; Hoberg, H. The process of separation of fine mineral particles by flotation with hydrophobic polymeric carrier. Int. J. Miner. Process. 1993, 37, 109-122. [CrossRef]

27. Arriagada, S.; Acuña, C.; Vera, M. New technology to improve the recovery of fine particles in froth flotation based on using hydrophobized glass bubbles. Miner. Eng. 2020, 156, 106364. [CrossRef] 
28. Hunter, T.N.; Wanless, E.J.; Jameson, G.J. Effect of esterically bonded agents on the monolayer structure and foamability of nano-silica. Colloids Surf. A Physicochem. Eng. Asp. 2009, 334, 181-190. [CrossRef]

29. Utsugi, H.; Horikoshi, H.; Matsuzawa, T. Mechanism of esterification of alcohols with surface silanols and hydrolysis of surface esters on silica gels. J. Colloid Interface Sci. 1975, 50, 154-161. [CrossRef]

30. Salmani Nuri, O.; Irannajad, M.; Mehdilo, A. Reagent adsorption on modified mineral surfaces: Isotherm, kinetic and thermodynamic aspects. J. Mol. Liq. 2019, 291, 111311. [CrossRef]

31. Du, Y.; Meng, Q.; Yuan, Z.; Ma, L.; Xu, Y. Study on the flotation behavior and mechanism of ilmenite and titanaugite with sodium oleate. Miner. Eng. 2020, 152, 106366. [CrossRef]

32. Meng, Q.; Yuan, Z.; Yu, L.; Xu, Y.; Du, Y.; Zhang, C. Selective depression of titanaugite in the ilmenite flotation with carboxymethyl starch. Appl. Surf. Sci. 2018, 440, 955-962. [CrossRef]

33. Xiao, W.; Ren, Y.-x.; Yang, J.; Cao, P.; Wang, J.; Qin, W.-q.; Qiu, G.-z. Adsorption mechanism of sodium oleate and styryl phosphonic acid on rutile and amphibole surfaces. Trans. Nonferrous Met. Soc. China 2019, 29, 1939-1947. [CrossRef]

34. Chen, P.; Lu, X.; Chai, X.; Mulenga, H.; Gao, J.; Liu, H.; Meng, Q.; Sun, W.; Gao, Y. Influence of Fe-BHA complexes on the flotation behavior of ilmenite. Colloids Surf. A Physicochem. Eng. Asp. 2021, 612, 125964. [CrossRef]

35. Chen, P.; Zhai, J.; Sun, W.; Hu, Y.; Yin, Z. The activation mechanism of lead ions in the flotation of ilmenite using sodium oleate as a collector. Miner. Eng. 2017, 111, 100-107. [CrossRef]

36. Fan, G.; Zhang, C.; Wang, T.; Deng, J.; Cao, Y.; Chang, L. New insight into surface adsorption thermodynamic, kinetic properties and adsorption mechanisms of sodium oleate on ilmenite and titanaugite. Adv. Powder Technol. 2020, 31, 3628-3639. [CrossRef]

37. Van Oss, C.J. Chapter Three-The Extended DLVO Theory. Interface Sci. Technol. 2008, 16, 31-48.

38. Adamczyk, Z.; Weroński, P. Application of the DLVO theory for particle deposition problems. Adv. Colloid Interface Sci. 1999, 83, 137-226. [CrossRef]

39. Piñeres, J.; Barraza, J. Energy barrier of aggregates coal particle-bubble through the extended DLVO theory. Int. J. Miner. Process. 2011, 100, 14-20. [CrossRef]

40. Mei, W.; Li, X.; Cao, Y. Chemical Formulas Manual; Transl. Scienmce Press: Beijing, China, 1987.

41. Oss, C.J.V.; Giese, R.F.; Costanzo, P.M. DLVO and non-DLVO interactions in hectorite. Clays Clay Miner. 1990, 38, 151-159.

42. Farahat, M.; Hirajima, T.; Sasaki, K.; Doi, K. Adhesion of Escherichia coli onto quartz, hematite and corundum: Extended DLVO theory and flotation behavior. Colloids Surf. B Biointerfaces 2009, 74, 140-149. [CrossRef] [PubMed] 